\title{
BETWEEN GENTRIFICATION AND REURBANISATION. THE PARTICIPATORY DIMENSION OF BOTTOM-UP REGENERATION IN GDAŃSK, POLAND
}

\begin{abstract}
GRABKOWSKA, M. (2015): Between gentrification and reurbanisation: The participatory dimension of bottom-up regeneration in Gdańsk, Poland. Geografie, 120, No. 2, pp. 210-225. - Urban regeneration has become a key issue in the development of contemporary cities. The paper discusses bottom-up regeneration practices performed by inhabitants of a decaying inner-city neighbourhood under post-socialist conditions, which differ notably from the widely researched Western European context. Results of a qualitative study in Wrzeszcz Dolny, Gdańsk, have indicated the leading role of newcomers to the area in animating bottom-up regeneration efforts, which in turn translate into an activation and integration of the local community. Thus, it is argued that an in-migration into the inner city, usually interpreted as gentrification, does not necessarily generate losses for the indigenous inhabitants but can also bring a desired social change and significantly contribute to the building of inclusive civil society. The presented case study therefore signals the need for a careful investigation and precise labelling of the post-socialist inner-city transformation processes, as well as demonstrates how increasing participation might be employed as the potential antidote to ills associated with gentrification.
\end{abstract}

KEY WORDS: gentrification - re-urbanisation - urban regeneration - bottom-up movements - social inclusion.

The article was developed with support from the National Science Centre (grant number DEC-2011/03/B/HS4/02302).

\section{Introduction}

Urban regeneration is a challenge which most contemporary cities need to face. A complex issue itself, it is yet more difficult to address in Central and Eastern Europe where the post-World War II decline of the inner city has been relatively more intense than on the other side of the Iron Curtain. A vast body of literature explains the reasons for this encumbrance, including ideological, economic, organisational and socio-demographic (Kaczmarek 2001, Billert et al. 2003, Murzyn 2004, Załuski 2004, Zborowski 2009, Lorens 2010, Haase et al. 2011).

In consequence, local governments across the region usually consider the need for urban regeneration to be an excessive burden and may be tempted to welcome the idea of gentrification as a remedy for inner-city deprivation (Badyina, Golubchikov 2005). From this perspective the attractiveness of gentrification lies in minimisation of expenditures to achieve material and economic renewal of areas in crisis. Such uncritical attitude towards gentrification, disregarding its considerable social costs, illustrates both the neoliberal pragmatism (Colomb 
2011) and insufficient knowledge of the process among the decision-makers. The latter could be related to deficiency of appropriate empirical research in the region, especially since the debate whether gentrification is at all present in Central European cities still continues. Although there has been some evidence of gentrified neighbourhoods in capital cities (Sýkora 2005), studies in secondtier and smaller urban centres have traced only marginal or 'pocket' gentrification (Matlovič, Sýkora, Szczyrba 2001; Marcińczak 2007; Grabkowska 2011a; Gądecki 2012; Liszewski, Marcińczak 2012, Kovács, Wiessner, Zischner 2013). Yet, some of them present the observed processes with severe criticism and a dose of anxiety concerning the potential threat of direct and indirect displacement to the existing local communities, which appears to be the standpoint quite opposite to the one of local authorities. There is, however, a general scarcity of publications on the subject and much of the existing literature is limited to a review of mostly Anglo-Saxon literature (Jadach-Sepioło 2009, Grzeszczak 2010). Furthermore, no attempts to propose explanatory alternatives to the theory of gentrification in Western Europe have yet been made.

On account of the relative newness of the phenomenon, as well as because of its limited recognition, any inner-city change involving in-migration is very often automatically labelled gentrification and showcased, both in academic literature and in the media, as a socially undesirable phenomena. However, residential change in post-socialist inner cities is not necessarily always detrimental. Thus, the aim of this paper is to fill the existing research gaps in terms of describing a concrete case study which shows how an inflow of new residents to a decaying neighbourhood may depart from the classic gentrification model and in fact be a combination of different socio-spatial processes which are closer to the concept of reurbanisation. Presented results of a research undertaken in Wrzeszcz Dolny, an old inner-city district of Gdańsk in Poland, illustrate this conceptual ambiguity and, moreover, explain ways in which social changes brought about by the newcomers to the area may be beneficial to the local community and contribute to urban regeneration. An empirical rather than a theoretical input to the debates on gentrification and reurbanisation processes in Central and Eastern Europe, it may well serve as a stepping stone towards the construction of a more general theory.

The applied methodology is mainly qualitative, featuring interviews, fieldwork, participant observation and content analysis, in a follow-up research of the author's previous studies in the area (Grabkowska 2012). By reason of an overall shortage of population data at the district or neighbourhood level in Gdańsk, the only statistics obtained from the Gdańsk Development Bureau, the local planning office, concern migration flows to and from Wrzeszcz Dolny in 2010 and 2013. Official numbers, based on the local residence registration (obligatory in Poland until $1^{\text {st }}$ of March 2013, although not too strictly executed in recent years), nevertheless are understated since a proportion of flats in the district is rented out informally by the owners in order to avoid taxpaying.

The starting point of the case-study investigation are 14 individual in-depth interviews with new residents ${ }^{1}$, urban planners, local housing administration

1 A pilot phase of the study included interviews with sitting tenants of municipal flats and long-term owner-occupiers as well. 
representatives and other experts in the field, results of which provide information on the incomers' socio-economic profiles, their motivations for moving into the district and undertaken activities within the local community, including bottom-up regeneration practices. This part of research was conducted between July 2007 and May 2008 and involved also listing of the service premises located along one of the main streets in the district. In order to trace functional changes the inventory was repeated in March 2015. To observe the further development of the neighbourhood changes the author assisted in participatory budgeting meetings run by the district council and a few cultural events organised topdown by the city authorities. These ethnographic methods are supplemented with content analysis of legal documents and media publications, a collection which provided a variety of data, coded an analysed altogether to obtain the fullest image of the transformation in Wrzeszcz Dolny.

The subsequent section of the paper briefly addresses the theoretical issues concerning the notions of gentrification and reurbanisation. Next, characteristics of post-socialist inner cities are discussed and the case study of Wrzeszcz Dolny is presented, followed by concluding remarks.

\section{Gentrification and reurbanisation - issues of definition}

Since Glass (1964) coined the term, gentrification has been essentially linked to displacement. According to this conception, inhabitants of run-down neighbourhoods are forced to move out subsequent to the arrival of new, more affluent residents who generate the rise of property values and rents to a level which is unaffordable for the former. Although the causes of gentrification are debatable - theoretical standpoints range from consumption-based (Ley 1997, 2003) and production-based (Smith 1979, 1996) to mixed approaches (Hamnett 1991; Lees 2000; Lees, Slater, Wyly 2008) - the mechanism of displacement as its undesired consequence is a staple ingredient across all theories (Palen, London 1984; Atkinson 2000). It is also commonly agreed that gentrification may be connected to urban regeneration, either as its result or else a substitute (Colomb 2007; Bromley, Tallon, Thomas 2005).

Meanwhile, van Criekingen and Decroly (2003) suggest to expand the catalogue of possible socio-spatial consequences of urban regeneration, including marginal gentrification and incumbent upgrading ${ }^{2}$. Their common feature is that they all consist in improvements to the built environment. Marginal gentrification, just like classic gentrification, involves social status growth and population change, but unlike classic gentrification does not result in a wealthy neighbourhood. This follows from the fact that the gentrifiers, often young artists and hipsters, are not much more affluent than the indigenous residents. Conversely, incumbent upgrading - which in fact is not a new concept (Clay 1979) - concerns improvements to the built environment carried out by existing residents and thus without social status growth or population change.

2 The classification also involves upgrading, which fulfils all of the criteria of gentrification, except that it occurs in relatively socially and materially sound neighbourhoods, not requiring prompt regeneration. 
Both examples demonstrate that gentrification should not be treated as the one and only explanation of social change and in many cases it could be more appropriate to use the term reurbanisation instead (cf. Haase et al. 2010). Identified as fourth and the last phase of the urbanisation process, following urbanisation per se, suburbanisation and deurbanisation (van den Berg et al., eds. 1982), it denotes the "return to the inner city". The list of publications on reurbanisation tendencies in Western European cities is quite abundant (Ogden, Hall 2000; Seo 2002; Haase, Kabisch, Steinführer 2005; Bromley, Tallon, Roberts 2007; Buzar et al. 2007). In Central and Eastern Europe the overwhelming majority of studies still focus on suburbanisation, one of the most pressing issues of post-socialist cities' development, which has lately reached its peak (Lorens 2005). Still, signs of reurbanisation have already been documented and it is expected that the trend will strengthen (Parysek, Mierzejewska 2005; Haase et al. 2011).

Reurbanisation, apart from its quantitative dimension which relates to the inner-city population growth, also comprises qualitative changes. For instance, Buzar et al. (2007, p. 652) identify reurbanisation "as a process of populating and diversifying the inner city with a variety of residential strata". New residents tend to represent social structures different to the existing local community, such as non-traditional households, but upon their arrival they rather mix in than displace. Therefore this approach places the emphasis on enriching the social mix instead of regarding the repopulation as invasion of socio-demographically alien groups of outsiders to the inner city.

Furthermore, reurbanisation can be understood not merely as the return to the (inner) city but also as remaking the city and/or reclaiming the right of the city. In the opening of his renowned manifesto Harvey (2008, p. 23) underlines the role of urban dwellers as potential key instigators of urban change.

The right to the city is far more than the individual liberty to access urban resources: it is a right to change ourselves by changing the city. It is, moreover, a common rather than an individual right since this transformation inevitably depends upon the exercise of a collective power to reshape the processes of urbanization.

This in some instances may apply to newcomers to neighbourhoods in crisis who initiate taking responsibility of the local environment by making use of their entrepreneurial skills and social competence, as evidenced in Wrzeszcz Dolny. In terms of urban regeneration, similar mechanisms translate to the empowerment of inhabitants of the inner city and their active participation in the process of renewal. Even though such bottom-up formula is increasingly employed in the West (Silverman, Patterson 2012), for reasons outlined in the next section it has hardly taken root in cities of Central and Eastern Europe.

\section{Specifics of the post-socialist inner cities in the context of urban regeneration: The case of Poland}

The post-socialist inner city is an amalgam of early capitalist urban space and socialist accretions (Liszewski 2001). It needs to be underlined that the degradation of the $19^{\text {th }}$ and early $20^{\text {th }}$ century built environment has continued 
long after the 1990s. During the socialist period the disinvestment of the inner city could be explained by the modernisation priorities of the socialist governments (Wiench 1989) and their ideological aversion to the remnants of the former system, embodied in the bourgeois tenement houses and villas. Since the transformation began, the material deterioration has been associated with the lack of proper funding. In countries which in 2004 accessed the European Union the regeneration efforts have considerably intensified but not immediately.

Another socialist legacy, the retained social mix, is however quite favourable. As a consequence of the policy to shuffle the upper, middle and working classes via the authoritative mechanism of flat assigning, the post-World War II socialist inner city became relatively desegregated compared to its capitalist counterpart. Even if after 1989 the segregation patterns have reappeared (Węcławowicz 1998), they are still not as pronounced as in the old capitalist cities. Because of the retained mix, the post-socialist inner city is undergoing simultaneous, yet often opposing socio-demographic processes. For instance, an observable out-migration to the suburbs (Kajdanek 2012) is counteracted by an inflow of new residents, while population ageing favours generational replacement and studentification.

Post-socialist urban regeneration apart from progressing slowly is usually top-down-oriented. In Poland its definition formulated by the Secretary of Regional Development (Wytyczne Ministra 2008) explicitly emphasises the superior position of the local government in planning and initiating regeneration practices, without making any reference to local communities as potential participants. The reluctance towards participatory approach is reflected in Local Regeneration Programmes which reveal scarcity of tools and their superficiality - for instance, public consultations, often the sole instrument applied, are usually limited to the minimum demanded by the EU funding requirements (Hałat 2010). In the same vein, as evidenced by Olech (2014), public participation in Polish cities is very often performed by local governments only through informing about decisions which have already been made. Singular cases of local authorities involving local communities in the regeneration process from beginning to the end (cf. Kipta 2008) are rather exceptions proving the rule. Generally low civic engagement in public matters, characteristic for post-socialist societies (Tworzecki 2008), has both generated and sustained this status quo.

Yet, the growing consciousness among urban dwellers, which has recently emerged in the form of urban movements claiming the right to the city, gradually changes the distribution of power and opens the floor to negotiating participatory urban planning and practices (Keresztély, Scott 2012; Sagan, Grabkowska 2012). Bottom-up regeneration may be regarded as the most advanced, or extreme, variant of participation - one which is the most spontaneous, voluntary and independent. It may be defined as grassroot activities of inhabitants of degraded inner-city neighbourhoods which lead to improvement of technical condition of housing as well as integration and empowerment of local communities (Grabkowska 2010). The local context conditions the scope and character of the changes. In the case study presented in the following section the ongoing privatisation of municipal flats in tenement houses and creation of commonholds (wspólnoty mieszkaniowe), associations of owners of individual 
flats who collectively manage the whole building, served for the catalyst for change. A decisive factor was nonetheless historical - unlike in Cracow or Warsaw restitution was almost non-existent, since the pre-World War II owners, mostly of German origin, rarely attempt to resume their lost properties in the Polish Regained Territories which belonged to Prussia before 1945.

\section{Bottom-up regeneration practices in Wrzeszcz Dolny, Gdańsk}

The path dependency of inner-city Gdańsk thus has been strongly shaped not only by the relatively recent socialist period, but also the more ancient history. Wrzeszcz Dolny, a former suburb of Gdańsk and now one of its central housing districts, with predominance of late $19^{\text {th }}$ and early $20^{\text {th }}$ century architecture and a dense population of over 24,000 inhabitants (Fig. 1), where the action of Günter Grass's famous novels is laid in (1976), provides a prime example of a cultural landscape that could be compared to a palimpsest. Located conveniently along the main communication axis of the Tricity agglomeration, which consists of Gdańsk, Gdynia and Sopot, even though Wrzeszcz Dolny is subjected to severe material and social degradation under socialism and suffering from a negative migration balance since the early $1990 \mathrm{~s}$, it is still perceived as quite an attractive place to live.

Due to considerable concentration of indicators of crisis, relatively higher than the city average, Wrzeszcz Dolny has been chosen as one of 13 priority areas in the Local Regeneration Programme - the first official document to tackle the issue of urban regeneration in Gdańsk (Program rewitalizacji 2004). Initially its implementation progressed slowly and focused mainly on renovation of several green spaces within the district. Around 2010 the approach altered to include the social dimension and fulfil the EU funding requirements. The total amount assigned for regeneration of Wrzeszcz Dolny amounted to 20.8 million PLN, of which 68.3 percent is covered from the structural funds. The highlight of the planned investments is renovation of Wajdeloty Street (Fig. 2), a significant communication axis of the neighbourhood, featuring implementation of a flood-control system, and limiting the traffic. Interestingly, its inclusion in the Programme is a result of bottom-up lobbying campaign, described further in the paper.

Despite the negative migration balance in Wrzeszcz Dolny in recent years there has been a significant in-migration to the district. In 2010 it accounted to 528 new inhabitants (as opposed to 964 emigrants), while in 2013 there were 403 incoming residents (and 814 moved out). As stated in the introduction, it may be assumed that these figures are in fact higher. Nevertheless, even

\footnotetext{
The selection criteria included the following indicators: high unemployment rate, low education level, low level of entrepreneurship, high degree of social exclusion and poverty, considerable pollution, large number of culturally valuable structures, bad technical condition of the existing development, insufficient or inoperative infrastructure, degraded areas of high economic potential such as post-industrial and postmilitary brownfields. In the updated version of the Programme (Program rewitalizacji 2009) the number of priority areas decreased to four, including Wrzeszcz Dolny.
} 


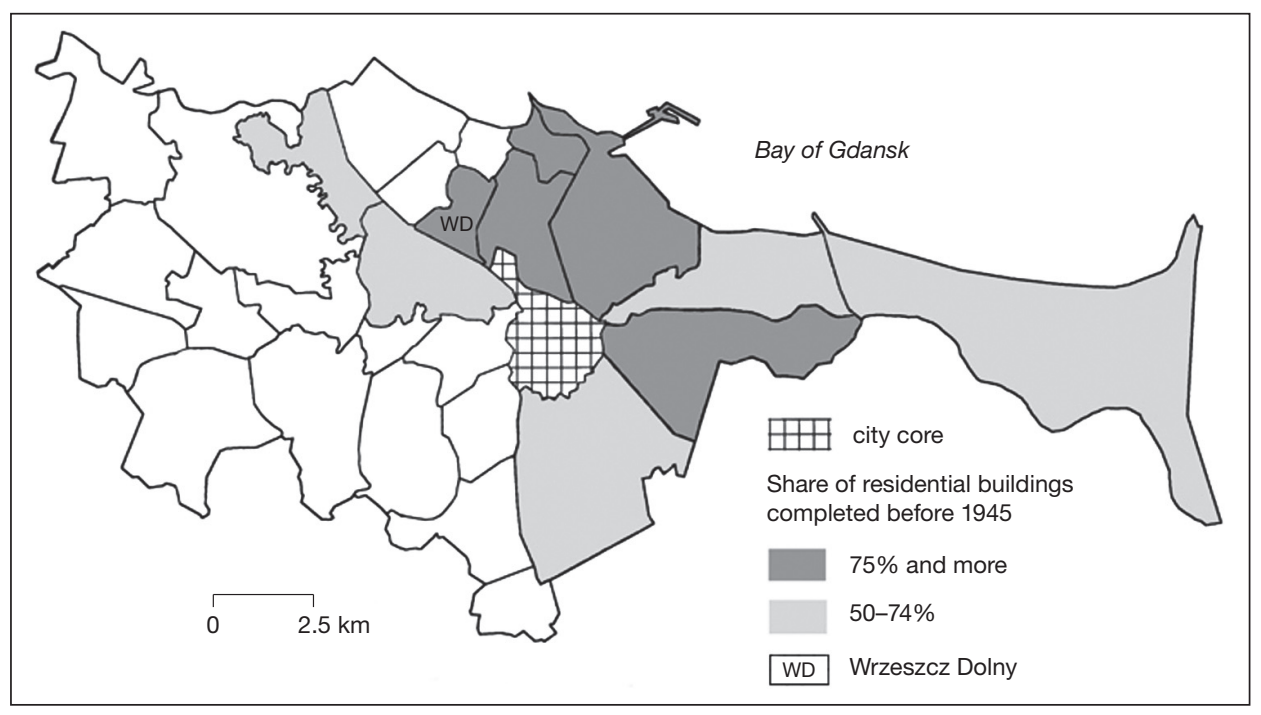

Fig. 1 - Location of Wrzeszcz Dolny within the inner city of Gdańsk. Source: Own elaboration based on National Census 2002 data.

if reliable statistics are unavailable, the growing presence of newcomers is observable in several ways.

Findings from the interviews reveal that within the last decade the social composition of the district has underwent a distinct transformation due to inflow of a new type of residents (Grabkowska 2011b). They are relatively younger than the average of the indigenous population, well-educated specialists or freelance workers, often single or representatives of other non-traditional households, such as flatshares. What is more, they tend to exhibit distinct urbanite lifestyles. On the one hand, they are drawn to Wrzeszcz Dolny because of its old-time atmosphere, on the other, they want to live close to the city centre in order to be able to enjoy its attractions without having to commute from distant suburbs. Flexibility is the word which appears in almost all of the accounts. It is used by the respondents to describe how living in the inner city allows them to reconcile work - not rarely performed at home - with leisure and family/social life. Many of them do not possess a car and hence they appreciate the well-developed public transport networks and the area's walkability.

Importantly, their arrival to Wrzeszcz Dolny did not involve direct displacement of indigenous residents. The tenure structure of flats with a predominance of private ownership is the crucial factor here. Some of the interviewees simply inherited flats from their grandparents, while other were bought from former municipal tenants who had acquired them from the council at over 90-percent discounts and voluntarily moved out to the suburbs. No evidence of indirect displacement has been confirmed by the interviewed experts either, even though the repeated inventory study of Wajdeloty Street reveals that a few local services, i.e. two beauticians, a hairdresser and a small grocery shop gave way to a vegan restaurant and cafe, a trendy pub and a pasta bar. This together with a Streetwaves open-air festival, with thousands of participants 

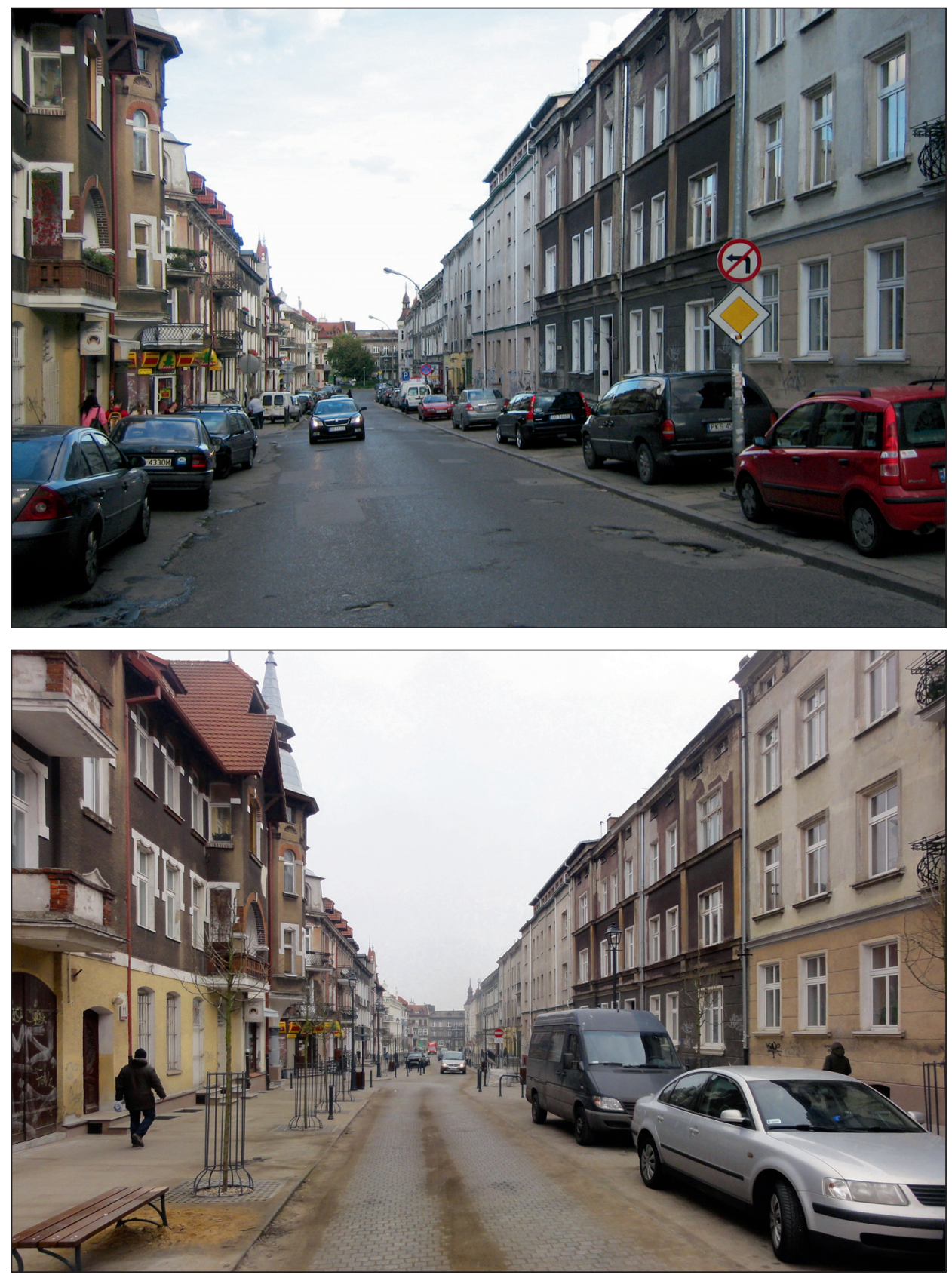

Fig. 2 - Wajdeloty Street as of September 2011 (top) and February 2015 (bottom) - before and after renovation. Photo: M. Grabkowska. 
invading Wrzeszcz Dolny for a day in June 2014 launched a heated debate on the ongoing neighbourhood changes and the potential "threat" of gentrification (Sandecki 2014, Dwojacki 2014, Cyrzan 2014, Grabkowska 2014).

However, the privatisation processes and the specific tenure structure paradoxically so far have prevented the undesirable effects of classic gentrification ${ }^{4}$. At the same time, the newcomers tend to readily engage in bottom-up regeneration. This happens mostly through their activity in the commonholds - many of the interviewees have become their leaders and managed to mobilise neighbours in successive renovation of the tenement houses. Accordingly, it may be stated that the in-migration to the district stimulates incumbent upgrading. In some cases, the leadership extended to establishing associations and local initiatives which concern larger units of the neighbourhood. For instance, an association lobbying for renovation of Wajdeloty Street, run by a quite recent newcomer to the district, through organising two street festivals and doorto-door campaign succeeded in collecting over a thousand signatures of local inhabitants supporting the idea and convinced the decision-makers to include the investment in the regeneration programme $\mathrm{s}^{5}$. Another initiative, coordinated by a different interviewee, was a series of thematic walks introducing the local community to the neighbourhood history, architecture which attracted a lot of participants and contributed to social integration and strengthening of the local identity (Szczepańska, Szczepański, eds. 2012).

The increasing empowerment and collective self-consciousness resulted in the formation of a district council in 2011. Several members of this most bottom-up sub-division of the local government also recruited from relatively new residents. Right from the beginning of its activity the council appeared as very pro-participatory and managed to organise two editions of participatory budgeting, in which the district inhabitants propose small investment or community projects and by voting decide on allocation of a large share of the district's budget (50,000 PLN in 2012 and 60,000 PLN in 2013). The number of submitted applications and attendance at the elections increased year by year and the winning projects included renovation of playgrounds in the neighbourhood, expansion of the collection of books in the local library, organisation of a district garden party, increasing the number of bicycle racks and equipping one of the parks with an open-air and open-access gym. Implementation of some of the projects was preceded by participatory planning workshops attended by local inhabitants - an innovative decision-making tool for the first time ever to be used in Gdańsk. This pioneer enterprise was copied by another district council in 2013 and in 2014 participatory budgeting was successfully introduced at the city level.

The research findings thus suggest that the reurbanisers in Wrzeszcz Dolny should be differentiated from Ley's "new middle class" gentrifiers. Not only their arrival does not generate direct displacement but their activity fosters

4 Nonetheless it should be noted, that the council's eagerness to sell out municipal housing stock to the sitting tenants dangerously balances on the verge of the willingness to get rid of the troublesome maintenance.

5 The progress of the renovation, which started in March 2013, was documented and watchdogged by one of the residents via a specially dedicated blog (Re: Wajdeloty 2013). 
social integration and empowerment of the local community. A possibly most appropriate term which could be used to describe this "new class" would be urbanogentsia, proposed by Galent and Kubicki (2011, p. 133) to describe city-minded contemporary urban dwellers who redefine civic engagement, coming up with new forms and frames of references. In Wrzeszcz Dolny the newcomers have become natural leaders because they appear to be relatively better equipped with appropriate knowledge and social capital, which helps them mobilise indigenous residents. Even if the motives of the respondents' involvement in bottom-up regeneration are partly materialistic, i.e. following from their wish to increase the value of the flats they own, many of them also mentioned post-material reasons, such as satisfaction with their work for the common good.

Due to the arguments outlined above, the consequences of the ongoing reurbanisation processes observed in Wrzeszcz Dolny may not be classified as classic gentrification. It is rather a combination of marginal gentrification and incumbent upgrading which have a similar effect but lack the key element of gentrification, namely displacement. Furthermore, unlike gentrification, they have desired social outcomes in the form of bottom-up regeneration and grassroot activism at the neighbourhood level.

\section{Conclusions}

Gentrification certainly is a useful concept to apply in contemporary urban studies. It serves to explain one of the most powerful processes reshaping the socio-spatial landscapes of many (inner) cities. Nonetheless, various findings suggest that it is not always applicable in the post-socialist context and that, at least up-to-date other concepts seem to better describe the ongoing changes. This may follow from such local specifics as the domination of private ownership of inner-city flats and small proportion of rentals or the housing shortage which has prevented major depopulation of the inner neighbourhoods throughout the past decades. The case study presented in the paper provides an example how reurbanisation may be a more appropriate term than gentrification. Reurbanisation tendencies have the capacity to encourage bottom-up regeneration, foster social integration and civic engagement as well as improve quality of life of both new and indigenous residents of the reurbanised area with minimum risk of social costs such as displacement. Among the benefits of bottom-up regeneration, apart from the improvements in the technical condition of the built environment, one can thus list effectiveness and inclusiveness which strengthen the district's development potential and ensure sustainability of the regeneration effects.

It cannot be ruled out that classic gentrification appears in post-socialist inner-city neighbourhoods like Wrzeszcz Dolny in future. It is however highly possible that the activation of the local community as a result of reurbanisation and subsequent bottom-up regeneration will either prevent or limit its undesired consequences. The participatory dimension of bottom-up regeneration may hence be the key to empowerment of local communities in decayed neighbourhoods and the means of driving them out of stagnation. While marginal 
gentrification, i.e. the inflow of new residents with suitable social capital, can boost incumbent upgrading, it is the involvement of the "older" inhabitants which guarantees the sustainability of the regeneration process. Further research is nonetheless necessary to monitor the progress of events, not only in Wrzeszcz Dolny but in other post-socialist inner cities as well, and to enable new explanatory frameworks. For the time being, reurbanisation would be the term to use, alongside the marginal gentrification, incumbent upgrading and other similar definitions which may be less general and therefore more applicable.

\section{References:}

ATKINSON, R. (2000): The hidden costs of gentrification: Displacement in central London. Journal of Housing and the Built Environment, 15, pp. 307-326.

BADYINA, A., GOLUBCHIKOV, O. (2005): Gentrification in central Moscow: A market process or a deliberate policy? Money, power and people in housing regeneration in Ostozhenka. Geografiska Annaler B, 87, pp. 113-129.

BILLERT, A., BEHR, I., KRÖNING, W., MUZIOŁ-WĘCŁAWOWICZ, A. (2003): Podręcznik rewitalizacji. Zasady, procedury i metody działania współczesnych procesów rewitalizacji. Urząd Mieszkalnictwa i Rozwoju Miast. Warszawa, 144 pp.

BOMLEY, R.D.F., TALLON, A.R., THOMAS, C.J. (2005): City Centre Regeneration through Residential Development: Contributing to Sustainability. Urban Studies, 42, No. 13, pp. 2407-2429.

BROMLEY, R.D.F., TALLON, A.R., ROBERTS, A.J. (2007): New populations in the British city centre: Evidence of social change from the census and household surveys. Geoforum, 38, pp. 138-154.

BUZAR, S., OGDEN, P., HALL, R., HAASE, A., KABISCH, S., STEINFÜHRER, A. (2007): Splintering Urban Populations: Emergent Landscapes of Reurbanisation in Four European Cities. Urban Studies, 44, No. 4, pp. 651-677.

CLAY, P.L. (1979): Neighborhood renewal: middle-class resettlement and incumbent upgrading in American neighborhoods. Lexington Books, Lexington, 128 pp.

COLOMB, C. (2007): Unpacking New Labour's "Urban Renaissance" Agenda: Towards a Socially Sustainable Reurbanization of British Cities? Planning, Practice \& Research, 22, No. 1 , pp. $1-24$.

COLOMB, C. (2011): Staging the New Berlin: Place Marketing and the Politics of Urban Reinvention Post-1989. Routledge, Abingdon, 368 pp.

CYRZAN, N. (2014): Festiwal Streetwaves. «Ta impreza to hołd dla mieszkańców». Published on $9^{\text {th }}$ June 2014, http://trojmiasto.gazeta.pl/trojmiasto/1,35636,16123741,Festiwal_Streetwaves_Ta_impreza_to_hold_dla_mieszkancow_.html (8. 3. 2015).

DWOJACKI, P. (2014): "Wrzeszcz ożywić muszą lokalsi, a nie kosmici". Cd. dyskusji na temat Streetwaves. Published on $8^{\text {th }}$ June 2014, http://trojmiasto.gazeta.pl/trojmiasto/1,35636,16104438,_Wrzeszcz_ozywic_musza_lokalsi_a_nie_kosmici_Cd_.html\#ixzz3Tn0OjA6O (8. 3. 2015).

GALENT, M., KUBICKI, P. (2011): Not Just a Nation Set in Stone: The Undercurrents Making the National Structure More Porous. In: Guasti, P., Hronesova, J., Mansfeldova, Z. (eds.): The Nexus Between Democracy, Collective Identity Formation and Enlargement. Academy of Sciences of the Czech Republic, Prague, pp. 122-135.

GĄDECKI, J. (2012): I \ NH: Gentryfikacja starej części Nowej Huty? Wydawnictwo IFiS PAN, Warszawa, 295 pp.

GLASS, R., (1964): London: Aspects of Change. MacGibbon and Kee, London, 342 pp.

GRABKOWSKA, M. (2010): Liderzy wspólnot mieszkaniowych jako aktorzy w procesie rewitalizacji wybranych dzielnic Gdańska. Problemy Rozwoju Miast, 3, pp. 70-78. 
GRABKOWSKA, M. (2011a): Inner-City Transformations after Socialism. Findings from Interviews with Residents of Pre-War Tenement Houses in Gdańsk. Bulletin of Geography. Socio-economic Series, 15, pp. 17-29.

GRABKOWSKA, M. (2011b): Flexible Households, Flexible Dwellings, Flexible Neighbourhoods? In: Haase, A., Steinführer A., Kabisch, S., Grossmann K., Hall, R. (eds.): Residential Change and Demographic Challenge. The Inner City of East Central Europe in the $21^{\text {st }}$ Century. Ashgate, Aldershot, pp. 233-253.

GRABKOWSKA, M. (2012): Regeneration of the Post-socialist Inner City: Social Change and Bottom-up Transformations in Gdańsk. Pracownia, Gdańsk, 171 pp.

GRABKOWSKA, M. (2014): Miasto jest dla wszystkich. Czy jednak wszyscy potrafimy się nim dzielić? Published on $16^{\text {th }}$ June 2014, http://trojmiasto.gazeta.pl/trojmiasto/1,35636, 16162793,Miasto_jest_dla_wszystkich_Czy_jednak_wszyscy_potrafimy.html\#ixzz3Tn3yx$\mathrm{nmN}$ (8. 3. 2015).

GRASS, G. (1976): Dog years, Penguin Books, Middlesex, 589 pp.

GRZESZCZAK, J. (2010): Gentryfikacja osadnictwa. Charakterystyka, rozwój koncepcji badawczej i przegląd wyjaśnień. Instytut Geografii i Przestrzennego Zagospodarowania im. Stanisława Leszczyckiego, PAN, Warszawa, 123 pp.

HAASE, A., KABISCH, S., STEINFÜHRER, A. (2005): Reurbanisation of inner-city areas in Europe. Scrutinising a concept of urban development with reference to demographic and household changes. In: Sagan, I., Smith, D.M. (eds.): Society, economy, environment towards the sustainable city. Bogucki Wydawnictwo Naukowe, Gdańsk-Poznań, pp. 77-93.

HAASE, A., KABISCH, S., STEINFÜHRER, A., BOUZAROVSKI, S., HALL, R., OGDEN, P. (2010): Emergent spaces of reurbanisation: exploring the demographic dimension of inner-city residential change in a European setting. Population, Space and Place, 16, No. 5, pp. 443-463.

HAASE, A., STEINFÜHRER, A., KABISCH, S., GROSSMANN, K., HALL, R. (2011). Residential Change and Demographic Challenge. The Inner City of East Central Europe in the $21^{\text {st }}$ Century. Ashgate, Aldershot, $376 \mathrm{pp}$.

HAŁAT, P. (2010): Instrumenty partycypacji społecznej w Lokalnych Programach Rewitalizacji miast w Polsce. In: Skalski, K. (ed.): O budowie metod rewitalizacji w Polsce - aspekty wybrane. Instytut Spraw Publicznych UJ, Kraków, pp. 127-56.

HAMNETT, C. (1991): The Blind Men and the Elephant: The Explanation of Gentrification. Transactions of the Institute of British Geographers, 16, No. 2, pp. 173-189.

HARVEY, D. (2008): The Right to the City. New Left Review, 53, pp. 23-40.

JADACH-SEPIOŁO, A. (2009): Gentryfikacja w kontekście rewitalizacji. In: Zborowski, A. (ed.): Demograficzne i społeczne uwarunkowania rewitalizacji miast w Polsce. Instytut Rozwoju Miast, Kraków, pp. 125-135.

KACZMAREK, S. (2001): Rewitalizacja terenów poprzemysłowych. Nowy wymiar w rozwoju miast, Wydawnictwo Uniwersytetu Łódzkiego, Łódź, 141 pp.

KAJDANEK, K. (2012): Suburbanizacja po polsku. Zakład Wydawniczy NOMOS, Kraków, $252 \mathrm{pp}$.

KERTESZÉLY, K., SCOTT J.W. (2012): Urban Regeneration in the Post-Socialist Context: Budapest and the Search for a Social Dimension. European Planning Studies, 20, No. 7, pp. 1111-1134.

KIPTA, E. (2008): Rewitalizacja zaniedbanych dzielnic Lublina. Urbanista, 9, pp. 12-17.

KOVÁCS, Z., WIESSNER, R., ZISCHNER, R. (2013): Urban renewal in the inner city of Budapest: gentrification from a post-socialist perspective. Urban Studies, 50, No. 1, pp. 22-38.

LEES, L. (2000): A reappraisal of gentrification: towards a 'geography of gentrification'. Progress in Human Geography, 24, No. 3, pp. 389-408.

LEES, L., SLATER, T., WYLY. E. (2008): Gentrification. Routledge, London, 344 pp.

LEY, D. (1997): The New Middle Class and the Remaking of the Central City. Oxford University Press, Oxford, $400 \mathrm{pp}$.

LEY, D. (2003): Artists, Aestheticisation and the Field of Gentrification. Urban Studies, 40, No. 12 , pp. 2527-2544. 
LISZEWSKI, S. (2001): Model przemian przestrzeni miejskiej miasta postsocjalistycznego. In: Jażdżewska, I. (ed.): XIV Konwersatorium Wiedzy o Mieście. Łódzkie Towarzystwo Naukowe, Łódź, pp. 303-309.

LISZEWSKI, S., MARCIŃCZAK, S. (2012): Geografia gentryfikacji Łodzi: studium dużego miasta przemysłowego w okresie postsocjalistycznym. In: Jakóbczyk-Gryszkiewicz, J. (ed.): XXV Konwersatorium Wiedzy o Mieście. Wydawnictwo Uniwersytetu Łódzkiego, Łódź, pp. 71-87.

LORENS, P. (2005): Suburbanizacja w procesie rozwoju miasta postsocjalistycznego. In: Lorens, P. (ed.): Problem suburbanizacji. Urbanista, Warszawa, pp. 33-43.

LORENS, P. (2010): Rewitalizacja miast. Planowanie i realizacja. Wydział Architektury Politechniki Gdańskiej, Gdańsk, 181 pp.

MARCINCZAK, S. (2007): The socio-spatial structure of post-socialist Łódź, Poland. Results of National Census 2002. Bulletin of Geography. Socio-Economic Series, 8, pp. 65-82.

MATLOVIČ, R., IRA, V., SÝKORA, L., SZCZYRBA Z. (2001): Procesy transformacyjne struktury przestrzennej miast postkomunistycznych (na przykładzie Pragi, Bratysławy, Ołomuńca oraz Preszowa). In: Jażdżewska, I. (ed.): XIV Konwersatorium Wiedzy o Mieście. Łódzkie Towarzystwo Naukowe, Łódź, pp. 9-21.

MURZYN, M. (2004): From neglected to trendy. The process of urban revitalization in the Kazimierz district in Cracow. In: Sagan, I., Smith, D.M. (eds.): Featuring the quality of urban life in contemporary cities of eastern and western Europe. Bogucki Wydawnictwo Naukowe, Poznań, pp. 257-274.

OGDEN, P.E., HALL, R. (2000): Households, reurbanisation and the rise of living alone in the principal French cities, 1975-90. Urban Studies, 37, No. 2, pp. 367-390.

OLECH, A. (2014): Modele partycypacji publicznej w Polsce. In: Olech, A. (ed.): Dyktat czy uczestnictwo? Diagnoza partycypacji publicznej w Polsce. Instytut Spraw Publicznych, Warszawa, pp. 25-52.

PALEN, J., LONDON, B. (1984): Gentrification, displacement, and neighborhood revitalization. State University of New York Press, Albany, pp. 90-102.

PARYSEK, J.J., MIERZEJEWSKA, L. (2005): Między dezurbanizacją a reurbanizacją: nowe oblicze urbanizacji w Polsce. In: Jażdżewska, I. (ed.): XVIII Konwersatorium Wiedzy o Mieście. Wydawnictwo Uniwersytetu Łódzkiego, Łódź, pp. 47-56.

Program rewitalizacji obszarów zdegradowanych w Gdańsku (2004): Lokalny program rewitalizacji, Załącznik do uchwały nr XXIII/689/04 Rady Miasta Gdańska z dn. 29 kwietnia 2004 roku.

Program rewitalizacji obszarów zdegradowanych w Gdańsku (2009): Lokalny program rewitalizacji, Załącznik do uchwały nr XLVII/1308/10 Rady Miasta Gdańska z dn. 25 marca 2010 roku.

Re: Wajdeloty (2013): Retrieved from http://wajdeloty.tumblr.com/ (17. 6. 2013).

SAGAN, I., GRABKOWSKA, M. (2012): Urban Regeneration in Gdańsk, Poland: Local Regimes and Tensions Between Top-Down Strategies and Endogenous Renewal. European Planning Studies, 20, No. 7, pp. 1135-1154.

SANDECKI, M. (2014): Kulturalni barbarzyńcy najechali na Wrzeszcz. Kto jest organizatorem zgromadzenia? Adamowicz! Published on $3^{\text {rd }}$ June 2014, http://trojmiasto.gazeta. pl/trojmiasto/1,35636,16082158,Kulturalni_barbarzyncy_najechali_na_Wrzeszcz_Kto. html\#ixzz3Tn2Anyvy (8. 3. 2015).

SEO, J.-K. (2002): Re-urbanisation in Regenerated Areas of Manchester and Glasgow. Cities, 19, No. 2, pp. 113-121.

SILVERMAN, R.M., PATTERSON, K.L. (2012): Guest editor's introduction. Themed issue on inner-city empowerment and revitalization. Community Development, 43, No. 4, pp. 411-415.

SMITH, N. (1979): Toward a Theory of Gentrification: A Back to the City Movement by Capital, not People. Journal of the American Planning Association, 45, No. 4, pp. 538-548.

SMITH, N. (1996). The New Urban Frontier: Gentrification and the New Revanchist City. Routledge, London, 288 pp.

SÝKORA, L. (2005): Gentrification in post-communist cities. In: Atkinson, R., Bridge, G. (ed.): Gentrification in a Global Context. Routledge, London, pp. 90-105. 
SZCZEPAŃSKA, K., SZCZEPAŃSKI, J., eds. (2011): Wędrówki po Wrzeszczu. słowo/obraz terytoria, Gdańsk, $322 \mathrm{pp}$.

TWORZECKI, H. (2008): A disaffected new democracy? Identities, institutions and civic engagement in post-communist Poland. Communist and Post-Communist Studies, 41, pp. 47-62.

VAN CRICKIENGEN, M., DECROLY, J.-M. (2003): Revisiting the Diversity of Gentrification: Neighbourhood Renewal Processes in Brussels and Montreal. Urban Studies, 40, No. 12, pp. 2451-2468.

VAN DEN BERG, L., DREWETT, R., KLAASEN, L.H., ROSSI, A., VIJVERBERG, C.H.T., eds. (1982): Urban Europe: A Study of Growth and Decline. Vol. 1. Pergamon Press, Oxford, $162 \mathrm{pp}$.

WECŁAWOWICZ, G. (1998): Social polarisation in post-socialist cities: Budapest, Prague and Warsaw. In: Enyedi, G. (ed.): Social change and urban restructuring in Central Europe. Akadémiai Kiadó, Budapest, pp. 55-66.

WIENCH, J. (1989). Społeczne procesy degradacji centrów starych miast. In: Parteka, T. (ed.): Przestrzeń kulturowa w planowaniu przestrzennym. Biuletyn KPZK. PAN, 142, Warszawa, pp. 110-129.

Wytyczne Ministra Rozwoju Regionalnego w zakresie programowania działań dotyczacych mieszkalnictwa (2008): MRR/H/18(2)/08/08, Ministerstwo Rozwoju Regionalnego, Warszawa.

ZAŁUSKI, D. (2004): Rewitalizacja śródmiejskich terenów poprzemysłowych jako szansa odnowy miast polskich. In: Markowski, T. (ed.): Przestrzeń w zarządzaniu regionalnym i lokalnym. Biuletyn KPZK, 211, Warszawa, pp. 229-263.

ZBOROWSKI, A., ed. (2009): Demograficzne i społeczne uwarunkowania rewitalizacji miast w Polsce. Instytut Rozwoju Miast, Kraków, 207 pp.

\section{Shrnutí}

\section{MEZI GENTRIFIKACÍ A RE-URBANIZACÍ: PARTICIPATIVNÍ DIMENZE REGENERACE ODSPODA V POLSKÉM GDAŇSKU}

Regenerace městského prostoru představuje výzvu pro většinu současných měst. Ve městech střední a východní Evropy místní administrativy často považují městskou regeneraci za neúnosné břemeno a mohou tak být v pokušení považovat gentrifikaci za řešení sociální deprivace vnitroměstských oblastí. Většina dostupných studií, kterých ovšem stále není př́liš velké množství, však upozorňuje primárně na potenciální hrozbu přímého či nepřímého vytlačování existujících městských komunit. Vzhledem k relativní novosti daného fenoménu a omezenému povědomí je často každá změna vnitroměstského prostoru doprovázená imigrací považována za gentrifikaci a potenciálně negativní prvek. Sídelní změny v centrech post-socialistických zemí ale rozhodně nejsou vždy škodlivé. Cílem toho článku je ukázat, jak se př́liv nových obyvatel do upadající čtvrti může odlišovat od tradičního modelu gentrifikace a být spíše souhrou socio-prostorových procesů příbuzných více s fenoménem re-urbanizace. Výsledky výzkumu provedeného v Wrzeszcz Dolny potvrzují tuto konceptuální mlhavost a demonstrují způsob, jakým mohou být změny způsobené příchodem nových obyvatel prospěšné pro místní komunitu a přispívat $\mathrm{k}$ regeneraci městského prostoru. Vzhledem k nedostatku statistických dat pro úroveň městských částí je výzkum založen primárně na kvalitativní metodologii, včetně rozhovorů, terénního šetření, zúčastněného pozorování a obsahové analýzy v návaznosti na předchozí studie v oblasti. Základem této případové studie jsou hloubkové rozhovory s nově příchozími rezidenty a experty v daném oboru, což bylo klíčem k získání socio-ekonomického profilu nově příchozích a informace o jejich motivaci pro přesun či aktivitách podniknutých v rámci jejich nové komunity, včetně regeneračních praktik působících „odspodu“ (bottom-up). Přestože gentrifikace je nevyhnutelně spojena s populačním přesunem, van Criekingen a Decroly poukazují na potřebu rozšířit výčet možných socio-prostorových variant městské regenerace, například o marginální gentrifikaci či revitalizaci silami bydlících obyvatel. Tyto procesy se shodují v tom, že všechny zahrnují zlepšení stavu obytného prostředí (zejména s ohledem na postavené budovy). Gentrifikace by tak neměla 
být považována za jediné vysvětlení sociálních změn ve vnitroměstském prostoru a v mnoha případech by bylo vhodnější hovořit o re-urbanizaci, která v sobě také může zahrnovat kvalitativní změny. Nově příchozí bývají zpravidla nositeli jiných sociálních struktur než původní usedlíci, nicméně dochází v tomto ohledu spíše k mísení než k vytlačování.

Od začátku transformačního procesu byla materiální degradace post-socialistických vnitřních měst primárně otázkou nedostatečného financování. V důsledku vstupu do Evropské unie došlo v zúčastněných zemích $\mathrm{k}$ velké intensifikaci regeneračních úsilí, ačkoliv ne zcela okamžitě. Kromě toho, že městská regenerace v post-socialistických městech postupuje pomalu, je často také řízená striktně shora. V Polsku se neochota k participativním postupům nejvíce projevuje $\mathrm{v}$ místních regeneračních programech, které jsou často velmi povrchní a nedisponují dostatkem účinných nástrojů. Rostoucí povědomí městských obyvatel ale postupně přenáší rovnováhu moci ve prospěch vyjednávání a participativních forem městského plánování. Regenerace odspoda je primárně definována místními aktivitami obyvatel degradovaných vnitroměstských čtvrtí, které vedou ke zlepšení podmínek bydlení i posilování a emancipaci místních komunit.

Taková je právě situace Wrzeszcz Dolny, bývalého předměstí Gdaňsku a nyní jedné z předních rezidenčních čtvrtí. I přes velkou materiální a sociální degradaci během období socialismu a úbytek populace na začátku devadesátých let se stále jedná o atraktivní lokalitu. $\mathrm{Z}$ rozhovorů je patrné, že sociální skladba této městské části prošla $\mathrm{v}$ důsledku příchodu nových obyvatel výraznou transformací. Tyto do Wrzeszcz Dolny láká jednak historická atmosféra, na druhé straně blízkost městského centra, jehož služby a výhody tak mohou využívat bez dalekých cest do vzdálených předměstí. Jejich příchod do Wrzeszcz Dolny přitom nevyvolal žádné nucený odchod původních obyvatel, ani známky nepřímého vysídlování nejsou z pořízených rozhovorů patrné. Toto je do značné míry zapříčiněno zpo̊sobem privatizace a nájemním systémem, čímž se podařilo předejít některým nepříznivým dopadům klasické gentrifikace. Nově příchozí se navíc aktivně zapojují do regeneračních aktivit organizovaných odspoda, zejména skrze bytová družstva. V některých př́ípadech dokonce docházelo k zakládání asociací či místních iniciativ s přesahem nad rámec samotných komunit. Emancipace a zvyšování společného vědomí nakonec vyústilo v založení obecní rady. Rada se již od počátku projevovala jako obhájce principu participace a podařilo se jí dvakrát zrealizovat participativní rozpočet, v jehož rámci mohou obyvatelé navrhovat menší investice či komunitní projekty a hlasovat o směřování podstatné části obecních prostředků.

Výzkum tedy poukazuje na to, že nově příchozí do Wrzeszcz Dolny bychom měli odlišovat od gentrifikujících členů střední třídy, které popisuje Ley. Nejen že jejich příchod nezpůsobil odchod původních obyvatel, ale jejich činnost naopak posiluje sociální integraci a emancipaci místních komunit. Nově příchozí se v komunitách stávají přirozenými vůdci, protože přicházejí vybaveni potřebnými znalostmi a sociálním kapitálem, díky čemuž dokážou původní rezidenty lépe zmobilizovat. Procesy zdokumentované v Wrzeszcz Dolny tak více spadají do kategorie marginální gentrifikace či revitalizace silami bydlících obyvatel spíše, než by se daly klasifikovat jako klasická gentrifikace, nebot' jejich dopady neobsahují přesun původního obyvatelstva.

Tato případová studie je tak př́kladem situace, kdy lze hovořit spíše o re-urbanizaci nežli o gentrifikaci. Pochopitelně nelze vyloučit, že se gentrifikace objeví v post-socialistických městech a jejich vnitroměstských čtvrtích jako je Wrzeszcz Dolny v budoucnu. Je ale dost dobře možné, že aktivizace místní populace v důsledku re-urbanizace pomůže zabránit některým jejím negativním dopadům, či je alespoň omezit. Participativní povaha městské regenerace odspoda tak může být klíčem $\mathrm{k}$ emancipaci komunit $\mathrm{v}$ degradovaných čtvrtích a východiskem $\mathrm{z}$ jejich stagnace.

Obr. 1 -Poloha Wrzeszcz Dolny ve vnitřním městě Gdaňsku. V legendě: městské jádro, podíl obytných budov postavených před rokem 1945: 75 \% a více, 50-74 \%. Zdroj: vlastní zpracování na základě dat z Národního sčítání z roku 2002.

Obr. 2 -Ulice Wajdeloty v září 2011 (nahoře) a v únoru 2015 (dole) - před renovací a po renovaci. 
Authors' affiliation: University of Gdansk, Department of Economic Geography, Gdansk, Poland; e-mail:geomg@univ.gda.pl.

Initial submission, 2 July 2014; final acceptance 18 April 2015.

\section{Please cite this article as:}

GRABKOWSKA, M. (2015): Between gentrification and reurbanisation: The participatory dimension of bottom-up regeneration in Gdańsk, Poland. Geografie, 120, No. 2, pp. 210-225. 